\title{
How can straw incorporation management impact on soil carbon storage? A meta-analysis
}

\author{
Fei Lu
}

Received: 20 January 2014 / Accepted: 31 March 2014 / Published online: 18 May 2014

(C) Springer Science+Business Media Dordrecht 2014

\begin{abstract}
Straw incorporation (SI) is a common practice in China and has important implications for agricultural sustainability. This study aimed to quantitatively summarise the response of top soil $(0-20 \mathrm{~cm})$ carbon $(\mathrm{C})$ to SI under different agricultural management regimes. Results indicated that compared with straw removal (SR), SI significantly increased soil C storage by $12 \%$. Moreover, incorporation of chopped straw with tillage treatment (ploughing and rotary tillage) increased $\mathrm{C}$ storage compared to unchopped straw without tillage treatment. SI implementation with upland cropping, in the northwest and northeast resulted in higher $\mathrm{C}$ storage compared with rice cropping, and in the northern and southern regions. Changes in soil $\mathrm{C}$ were observed based on SI variables, including tillage and straw amounts in fine-textured soils, however straw amount rather than tillage treatment exhibited a greater influence on soil C in coarse-textured soils. We concluded SI implementation with increased amounts of chopped straw for a longer duration was favourable to soil $\mathrm{C}$ sequestration in Chinese croplands. Furthermore, we estimated if SI was popularised across all of China's agricultural regions, soil C sequestration potential would reach $48.2 \sim$ 56.2 $\mathrm{Tg} \mathrm{C}_{\text {year }}{ }^{-1}$. SI practices should therefore be encouraged.
\end{abstract}

Keywords China $\cdot$ Meta analysis $\cdot$ Soil carbon (C) sequestration $\cdot$ Soil carbon storage $\cdot$ Straw incorporation

\section{Introduction}

Cereal crops (e.g. rice [Oryza sativa], maize [Zea mays], and wheat [Triticum aestivum]) produce substantial straw amounts, and it is estimated that cereal straw is responsible for $75 \%$ of the total crop straw (Department of Science and Technology and Education, Ministry of Agriculture of the People's Republic of China, STEMOA 2010). Post-harvest straw management and utilisation, including burning, harvesting, and some degree of soil incorporation, are under increased scrutiny, and have complex social, economic and ecological implications (Gullett and Touati 2003; Powlson et al. 2011). In China, prior to the 1980s, crop straws were primarily used as cooking and heating fuels, or as forage and bedding for livestock. Since the 1990s, fossil fuels have replaced crop residues

F. Lu $(\bowtie)$

Research Center for Eco-Environmental Sciences, Chinese Academy of Sciences, Shuangqinglu 18, Beijing 100085, China

e-mail: feilu@rcees.ac.cn 
as the major energy source, and straw is commonly burned in fields following harvest, contributing to China's serious air pollution (Zhang 2000; Gullett and Touati 2003; Ye et al. 2010), and greenhouse gas emissions (Pan et al. 2011). Straw burning has recently been prohibited in China's major agricultural regions in the National Modern Agriculture Development Plan (2011-2015) (MOA 2011). Ministry of Agriculture (MOA) clearly encourages comprehensive utilisation of straws, including covering, burying, or returning straw to fields as organic fertilizer, rather than burning. Crop straws contain nutrients, such as $\mathrm{N}$ and organic $\mathrm{C}$, therefore straw removal by burning reduces soil fertility and organic matter, resulting in declines in soil quality (Lu et al. 2010a, 2010b; Powlson et al. 2011), and C and N losses (Dobermann and Fairhurst 2000). Pan et al. (2011) reported biochar addition was an alternative approach to improve soil quality, however due to biochar technological limitations, direct straw incorporation is more commonly applied in China. Currently, local environmental protection authorities are in charge of straw burning prohibition with assistance from associated local government departments. In turn, agricultural administrations provide the efforts to popularize and optimise the utility of straw, particularly straw return, in agricultural communities. These cumulative governmental efforts continue as an important driving factor to implement straw incorporation protocols.

Numerous investigations into SI effects on soil $\mathrm{C}$ have been conducted across China, and included different climatic conditions (Li et al. 2003; Lu et al. 2009), and durations (Rui and Zhang 2010). In fact, notable differences occur not only in climate, and durations, but also geography, soil type, cropping system, and crop variety in Chinese agricultural lands, therefore, there are a great diversity of SI management in different regions (Liu et al. 2001; Bi et al. 2008). However, less attention, was paid to different straw management protocols, for example, SI type (chopped and unchopped), cropping systems (upland and rice paddies cropping), and tillage (no tillage, ploughing or rotary tillage). A numbers of studies have conducted meta-analysis of soil $\mathrm{C}$ storage change under different agricultural management protocols in meta-analysis (Rui and Zhang 2010; Huang et al. 2012), however, soil C sequestration potential was not estimated. Meta-analysis is a robust tool with the potential to synthesize data from multiple locations, temporal variability in results, and draw consistent conclusions across studies (Gurevitch and Hedges 1999). In the present study, our overall objectives were as followings: (1) investigate how certain factors (e.g., SI type and amount, tillage type, cropping system, and experimental duration) influenced SI effects on soil C storage; and (2) estimate soil $\mathrm{C}$ sequestration potential using meta-analysis results.

\section{Materials and methods}

\subsection{Data collection}

We collected data on soil C storage from studies where SI was compared with SR in side-byside experiments. We performed an exhaustive literature survey in ISI-Web of Science, Google Scholar (Google Inc., Mountain View, CA, USA), and Chinese Journal databases (CNKI Databases and Wanfang Data, at www.cnki.net and www.wanfangdata.com.cn, respectively) for articles published before September 2013. Studies had to meet the following specific criteria: (1) soil C concentration or storage values were reported within the study; (2) field experiments were included: pot experiments, agroforestry systems or vegetable lands were excluded; (3) experimental periods were longer than 3 years; (4) only three crops were included in the analyses: rice, maize, and wheat, because these are the most common crops cultivated in China, and the amount of straw from these three crops account for $76 \%$ of the 
total straw (STEMOA 2010). Finally, Appendix lises 76 papers consisting of 159-paired soil C data met our inclusion criteria. The distribution of experimental field is shown in Fig. 1.

A meta-analysis requires every measurement is statistically independent (Gurevitch and Hedges 1999), therefore, multiple measurements conducted in single-field experiments using the same SI treatment were averaged. In addition, different SI treatment amounts within a single study were assumed to be independent cases (Curtis and Wang 1998). Furthermore, we restricted our analyses to the latest sampling dates.

Means and standard deviations and replications of soil C concentrations and storage in SR and SI were obtained from tables and text, or extracted from figures using digitizing software (Grafula 3 v.2.10, Wesik SoftHaus, St Petersburg, Russia). The ancillary information on bulk density, texture, tillage type, crop straw status and amount incorporated, cropping system, experimental region, and duration were also collected. Most studies provided bulk density (BD) values, but where it was not reported, we applied $\mathrm{BD}=1.377 \times \mathrm{e}^{-0.0048 \times \mathrm{SOC}}$ to estimate soil BD values (Song et al. 2005). Soil organic C concentration, BD and soil depth $(20 \mathrm{~cm})$ were multiplied to calculate soil $\mathrm{C}$ stock $\left(\mathrm{t} \mathrm{ha}^{-1}\right)$ at a depth of $0-20-\mathrm{cm}$.

\subsection{Meta-analysis}

A meta-analysis was conducted to detect soil C storage response to SI. The response ratio InR (1), was used to estimate the effect size of SI:

$$
\operatorname{In}(R)=\operatorname{In}\left(\frac{\overline{X_{S I}}}{\overline{X_{S R}}}\right)
$$

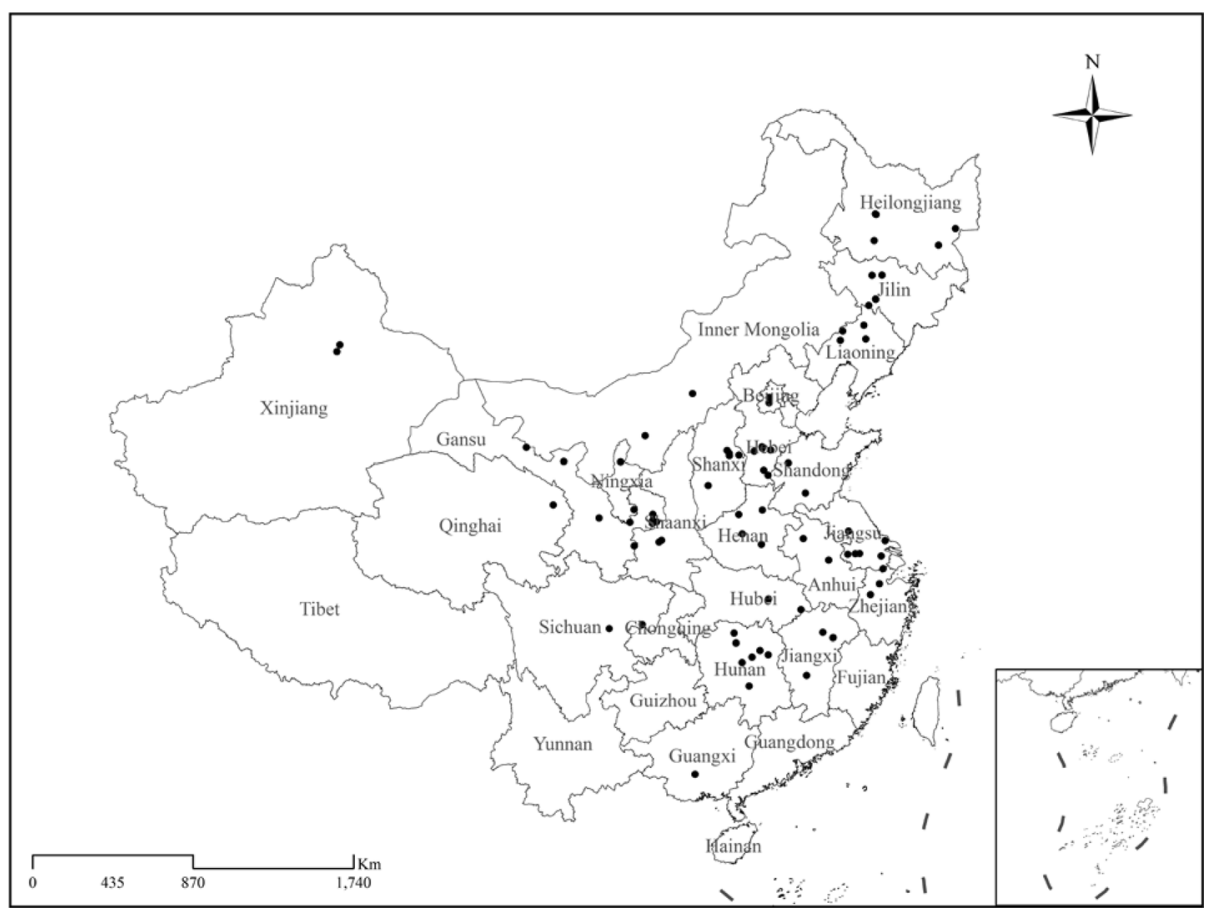

Fig. 1 The distribution of experimental straw study sites in China 
where, $\overline{X_{S I}}$ and $\overline{X_{S R}}$ are mean soil C storage values for SI and SR treatments, respectively. Metaanalysis results were reported as percentage changes, calculated as (R-1) $\times 100 \%$ (Curtis and Wang 1998; Morgan et al. 2003; Feng et al. 2006; Wittig et al. 2007). Negative percentage changes indicate decrease mean soil $\mathrm{C}$ storage values based on SI application, and positive values indicated an increase in mean soil $\mathrm{C}$ storage values.

An unweighted meta-analysis was adopted because most of the collected papers did not provide a measure of variance for soil C storage (Gurevitch and Hedges 1999; Rosenberg et al. 2000). Metaanalysis was performed using a meta-analytical software package (METAWIN 2.1.3.4, Sinauer Associates, Inc., Sunderland, MA, USA) (Rosenberg et al. 2000) following the method reported by Curtis and Wang (1998). The variance of effect sizes were calculated using resampling techniques after 4,999 iterations, and the confidence limits around the effect sizes were calculated using a bootstrap method (Rosenberg et al. 2000). The cumulative effect sizes were considered significant if the $95 \%$ confidence intervals (CI) did not overlap zero (Curtis and Wang 1998).

The variation in soil C storage response to SI was further explained by categorising, the paired measurements according to (1) SI type (chopped, unchopped); (2) tillage type (no tillage -NT, ploughing tillage -PT, and rotary tillage -RT); (3) cropping system (rice-rice, wheat-rice, wheatmaize, and single maize/wheat); (4) experimental duration ( $<5$ years, 5-15 years, $>15$ years); (5) experiment region (northeast, north, northwest, and south); (6) soil texture (fine-textured soils, and coarse-textured soils); (7) SI amount (half, and full SI). Random effects models facilitate comparisons among groups in a framework similar to analysis of variance, and thus a random effect categorical summary analysis was used to compare the variance in effect sizes. We accepted the tests of betweengroup heterogeneity $\left(\mathrm{Q}_{\mathrm{b}}\right)$ as statistically significant, if the $P$ values were less than 0.05 level.

\subsection{Annual soil $\mathrm{C}$ sequestration rates}

The annual soil $\mathrm{C}$ sequestration rate $(\Delta D y r)$ for soil $\mathrm{C}$ storage $\left(\mathrm{t} \mathrm{ha}^{-1}\right.$ year $\left.^{-1}\right)$ in response to $\mathrm{SI}$ versus SR was calculated by the following equation (2):

$$
\Delta D y r=\frac{\left(D_{S I}-D_{S R}\right)}{t}
$$

where, $D_{S I}$ and $D_{S R}$ are the corresponding C storage values for the SI and SR variables, respectively, and $t$ is the number of years SI had been implemented.

\section{Results}

In general, relative to SR, a significant increase (CI $>95 \%)$ in soil $\mathrm{C}$ storage was detected following SI implementation (Figs. 2 and 3), as expected. Compared with SR, SI increased soil C storage by $12 \%$ at 0 to $20 \mathrm{~cm}$ depths. Results indicated significant between-group heterogeneity $\left(\mathrm{Q}_{\mathrm{b}}\right)$ among SI type, tillage, cropping system, experimental duration, and region for the soil C storage (Table 1). Mean soil C storage differences in SI compared to SR showed a $9 \%$ increase in unchopped and $13 \%$ increase in chopped straw (Fig. 2). RT and PT increased soil C storage following SI compared to NT. SI effects significantly increased soil C storage by respective averages of 9,12 , and $16 \%$ in NT, PT, and RT. Soil C was also influenced by cropping system. Changes in soil C storage following SI treatment compared to SR was in the following order: single maize and wheat, wheat-maize $>$ wheat-rice, and rice-rice (Fig. 2). Soil C storage following SI was higher in the northeast and northwest regions (average 55.22 and $63.67 \mathrm{~kg} \mathrm{C} \mathrm{ha}^{-1}$ year $^{-1}$ ) than in northern and southern regions (average 38.35 and $56.05 \mathrm{~kg} \mathrm{C}^{-1}$ year $^{-1}$ ) (Fig. 3, Table 2). Annual soil C 


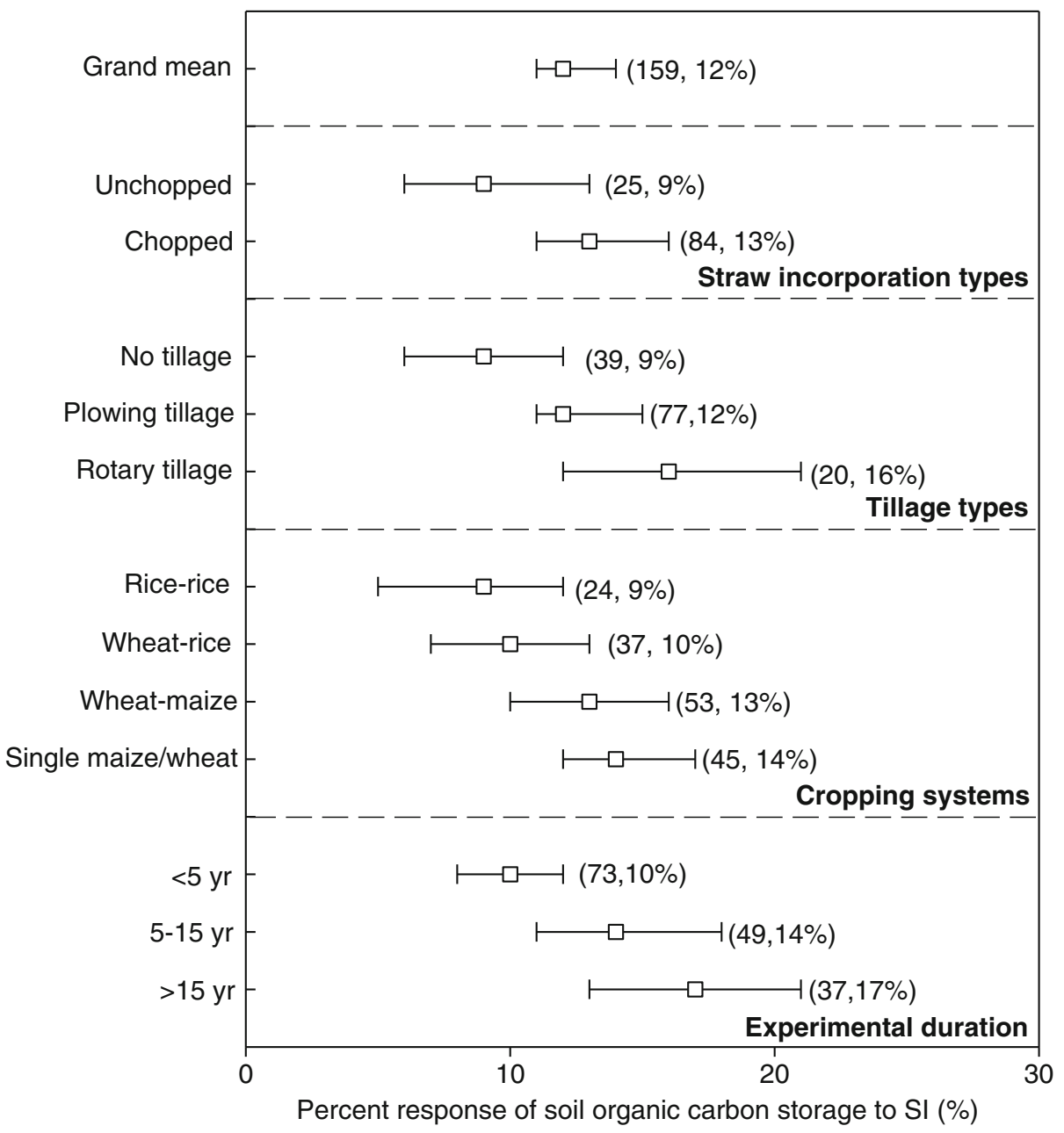

Fig. 2 Response of soil organic C storage to SI under different SI types, tillage types, rotation types, and experimental duration Dot and bar represent the mean and range at $95 \%$ confidence intervals of percent response to SI as compared to straw removal. The values in parentheses represent independent sample size and percent response to SI

sequestration rates due to SI showed a linear increase with increasing straw amounts (Fig. 4). Experimental duration also exhibited a significant effect on $\mathrm{C}$ storage response to SI, with a progressive increase in the response as the experimental duration increased (over 15 years $>5$ 15 years $>$ less 5 years) (Fig. 2). Results from the regression model revealed the majority of the increase in $\mathrm{C}$ storage occurred within the first 15 years (Fig. 4).

Overall, no significant $\mathrm{Q}_{\mathrm{b}}$ for soil $\mathrm{C}$ storage among soil texture categories was observed (Table 1). However, in fine-textured soils, SI resulted in significant soil C storage variability under different tillage treatments (Fig. 5). PT treatment showed a greater increase in C storage (16\%) compared to NT and RT (5\%). In contrast, SI and tillage treatment had no significant effect on $\mathrm{C}$ storage in coarse-textured soils. Soil $\mathrm{C}$ storage was sensitive to SI amount, and progressively increased with SI amount, regardless of fine or coarse textured soil. 

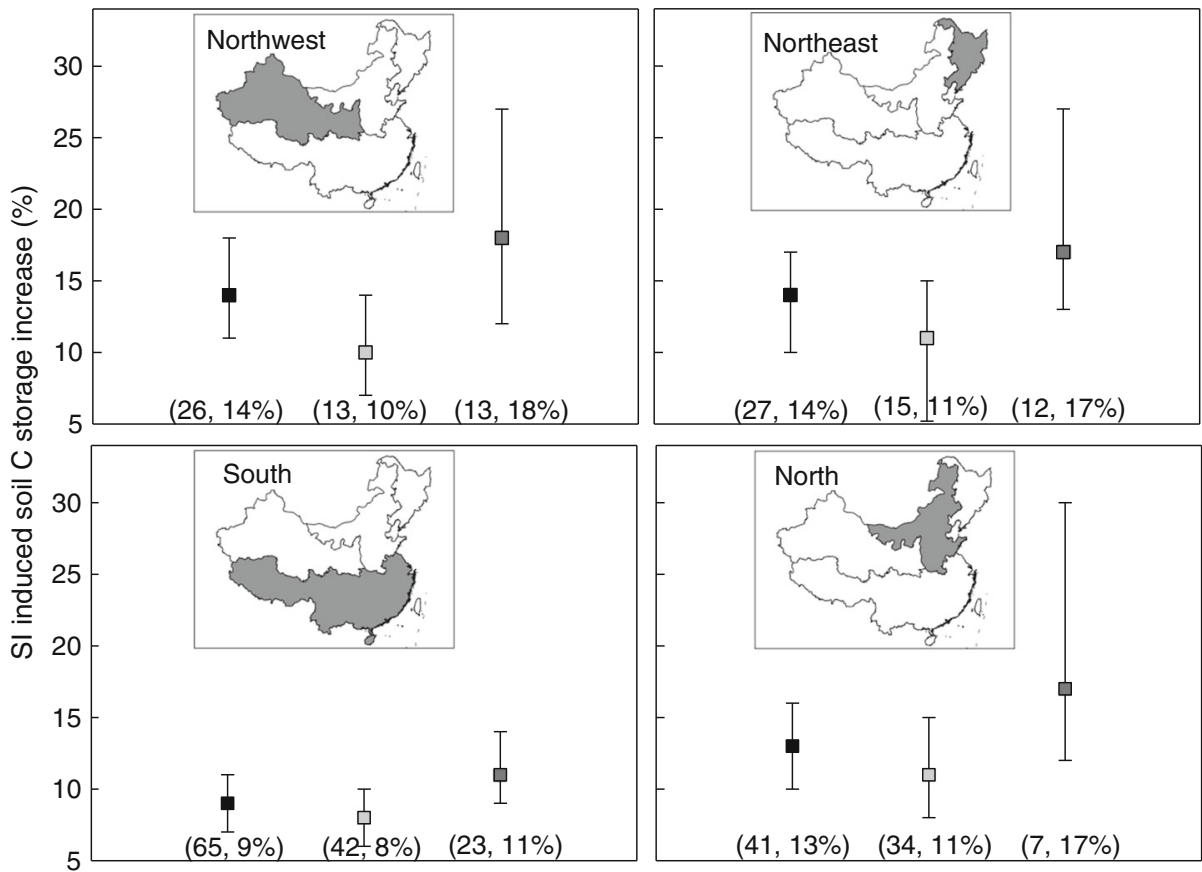

Overall Half amount Full amount

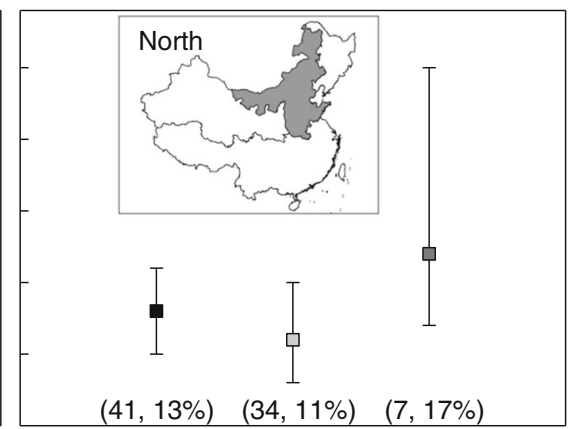

Percent response of soil organic C storage to SI under different straw amount(\%)

Fig. 3 Response of soil organic C storage to SI in different regions of China

\section{Discussion}

\subsection{SI effects on soil C}

Meta-analysis results from empirical cropland field study data derived from the literature showed SI generally resulted in increased soil C storage compared to SR treatments in surface $(0-20 \mathrm{~cm})$ soils (Kwabiah et al. 2003; Smith 2004; Wu et al. 2007; Saffih-Hdadia and Mary 2008; Powlson et al. 2011; Xu et al. 2011). SI provided large quantities of organic C inputs to cropland soils absent under SR, thereby promoting soil microbial biomass and its activity, and subsequently increasing soil organic matter (Dick 1992; Lal et al. 2007). Therefore, we conclude SI exhibited efficacy in increasing soil $\mathrm{C}$ storage.

Our results found SI effects on soil C storage were dependent on several factors, including type (chopped and unchopped) and amount of straw, tillage treatment (NT, PT, and RT), cropping system (rice-rice, wheat-rice, wheat-maize, and single maize/wheat), experimental region (northeast, north, northwest, and south), and duration ( $<5$ years, 5-15 years, $>15$ years).

Table 1 Effects of SI on between-group heterogeneity for soil organic C storage

\begin{tabular}{llllllll}
\hline & Number & SI type & Tillage & Cropping system & Duration & Regions & Texture \\
\hline Soil organic C storage & 159 & $4.1 *$ & $7.3^{*}$ & $9.4^{*}$ & $11.6^{* *}$ & $7.9^{*}$ & 1.2 \\
\hline
\end{tabular}

$* P<0.05, * * P<0.01$ 
Table 2 Typical properties and mean annual change rate of soil $\mathrm{C}$ storage (AMC) after SI in different agricultural regions

\begin{tabular}{llll}
\hline Region & Number of crops sown per year & Major crops & AMC (kg C ha year $\left.^{-1}\right)$ \\
\hline Northeast & Single crop & Maize, rice, wheat & 55.22 \\
Northwest & Single crop & Maize and wheat & 63.67 \\
North & Double crop & Maize and wheat & 38.35 \\
South & Double crop & Wheat and rice & 56.05 \\
\hline
\end{tabular}

Compared to unchopped straw, chopped straw exhibited a greater increase in soil C sequestration (Fig. 2). Chopped straw increases contact between the straw and soil microorganisms, which promotes the decomposition from straw into soil C. Alternatively, unchopped straw reduces contact between straw, soil, and soil microflora, decreasing decomposition and $\mathrm{C}$ sequestration. Therefore, chopped straw should be encouraged to enhance soil C sequestration.

NT treatment resulted in the absence of soil disturbance, with the straw remaining on the soil surface. In contrast, under RT and PT treatments, an excess of 90 and $60 \%$ of incorporated straw might be buried at depths of 0-11 cm and 10-20 cm, respectively (Allmaras et al. 1996). Li et al. (2001) reported straw decomposition rates were closely related to SI depths, in decreasing order from 5 to $15 \mathrm{~cm}$ to the surface soil. Thus, compared with NT, tillage treatments have increased the potential to promote straw $\mathrm{C}$ conversion into soil $\mathrm{C}$ (Stemmer et al. 1999; Wingeyer et al. 2012). It is noteworthy that NT treatment generally results in greater soil C storage than PT and RT treatments at surface soil (Bossuyt et al. 2002; Dolan et al. 2006; Huggins et al. 2007; Hermle et al. 2008). Six et al. (2002) proposed C-saturation mechanisms where larger amounts of soil $\mathrm{C}$ accumulate when $\mathrm{C}$ is far from saturation. Therefore, we can conclude RT and PT management regimes were more favourable than NT to soil C accumulation under SI conditions.

Our results found SI adoption with upland cropping in northwest and northeast regions of China showed higher $\mathrm{C}$ storage increase compared with rice cropping in northern and southern regions. Furthermore, the C-saturated model (Six et al. 2002) might contribute to these observations. First, due to anaerobic conditions (Witt et al. 2000; Yu et al. 2009), ricecropping systems (primarily located in the southern region) are generally associated with higher

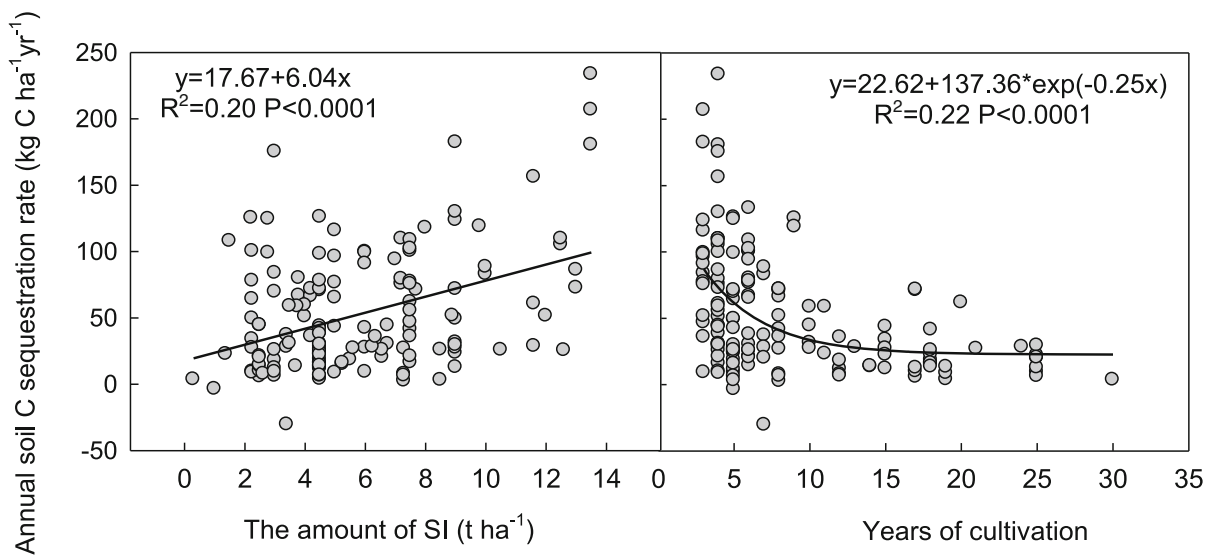

Fig. 4 The relationship between soil C sequestration rate and different amounts of SI and years of cultivation 


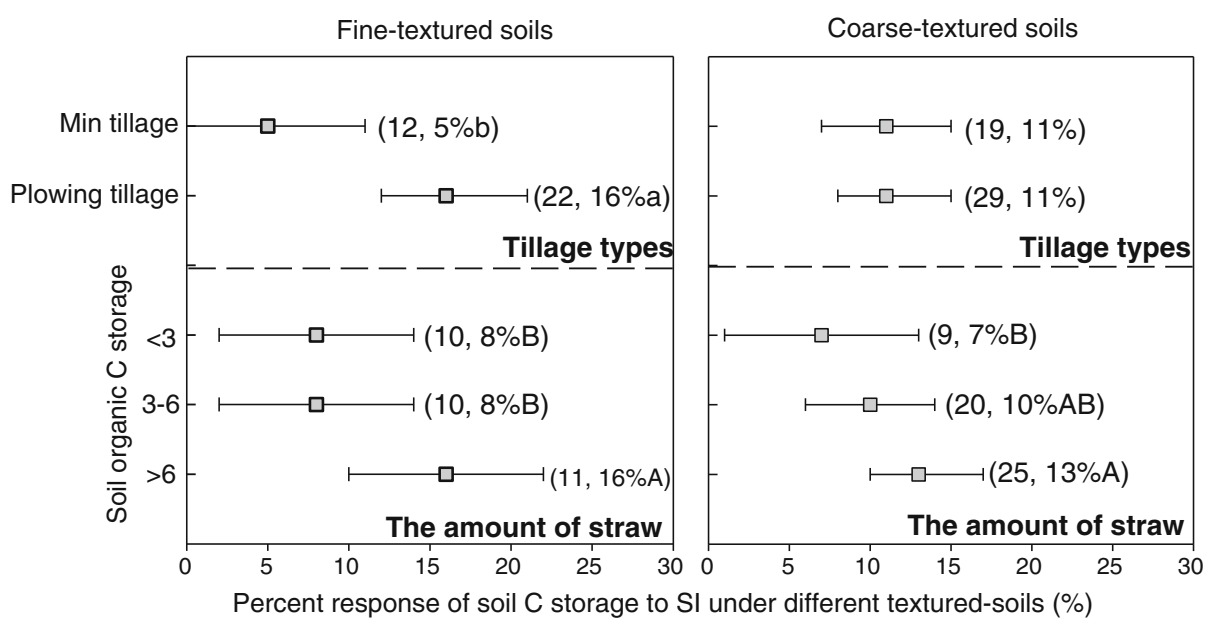

Fig. 5 Response of soil C to SI under different tillage types, and straw amount in fine and coarse textured soils. The unit of straw amount is $\mathrm{t} \mathrm{ha}^{-1}$. Different lowercase letters indicate significant difference of soil $\mathrm{C}$ storage between min tillage (no tillage and rotary tillage) and ploughing tillage after adoption of SI, different capital letters present significant different of soil C storage among different $\mathrm{SI}$ amount $(P<0.05)$

soil C storage than upland-cropping soils in China (Xie et al. 2007; Pan et al. 2010; Yu et al. 2012). Huang et al. (2012) conducted a national scaled meta-analysis that compared no fertiliser treatment and initial soil $\mathrm{C}$ values, and reported rice-rice rotation promoted a slight gain in soil C under the absence of fertiliser and straw treatments. Second, intense cropping systems might cause increased soil C storage compared to fallow soil (West and Post 2002; Álvaro-Fuentes et al. 2009), therefore single maize or wheat cropping systems corresponded to lower soil C storage due to decreased $\mathrm{C}$ input. Third, considerable evidence confirmed northwest and northeast regions of China are still experiencing considerable C losses (Yu et al. 2009, 2012; Wang et al. 2013), with some soil types in the northwest region exceeding over $50 \% \mathrm{C}$ loss during a short time (Wu et al. 2004). Based on these studies, we concluded that soils suffering from $\mathrm{C}$ loss, or further from $\mathrm{C}$ saturation have greater potential for soil $\mathrm{C}$ sequestration following SI implementation. Moreover, rice-cropping systems were associated with a warmer climate and anaerobic conditions, which accelerated $\mathrm{CH}_{4}$ emissions and straw decomposition (Devêvre and Horwáth 2000), therefore less C was accumulated than colder upland cropping.

Our results also indicated increased SI duration resulted in higher soil $\mathrm{C}$ sequestration (Fig. 2), however annual soil $\mathrm{C}$ sequestration rate gradually decreased over the experimental period (Fig. 4). C-saturation mechanisms (Six et al. 2002) might be responsible for these results, i.e. increased soil $\mathrm{C}$ diminished over time as a steady state was achieved (West and Post 2002; Kimetu et al. 2009; Luo et al. 2010). Therefore, SI implementation enhanced soil C storage only over periods of approximately 20 years (Luo et al. 2010; Rui and Zhang 2010). Although soil C sequestration rate decreased with experimental duration, long-term SI was still encouraged to increase soil $\mathrm{C}$ sequestration.

Lal (2004) reported optimum soil C stock could maintain water and nutrient levels, and improve soil structure, therefore we deduced that SI not only enhanced soil C storage, but also had an integral affect on crop yield (Lal 2004; Lal et al. 2007; Pan et al. 2009). Fifty-five paired measurements, including changes in crop yield due to SI were analysed in this study. Results showed SI increased crop yield by $0.143 \mathrm{t} \mathrm{ha}^{-1}$ year ${ }^{-1}$. Linear regression indicated annual soil $\mathrm{C}$ sequestration rate $\left(\mathrm{Y}, \mathrm{kg} \mathrm{C}^{-1}\right.$ year $\left.^{-1}\right)$ was positively related to the annual crop yield rate, i.e. $\mathrm{X}, \mathrm{t} \mathrm{ha}^{-1}$ year $^{-1}, \mathrm{Y}=30.44+206.2 \mathrm{X}\left(\mathrm{R}^{2}=0.44, P<0.01\right)$. 
Table 3 Two potential scenarios of SI in China

\begin{tabular}{lllll}
\hline Scenario & Northeast & Northwest & North & South \\
\hline I & $100 \%$ SI & $100 \%$ SI & SI for one of the two crops & $\begin{array}{c}\text { SI for one of the two crops } \\
\text { II }\end{array}$ \\
$100 \%$ SI & $100 \%$ SI & $\begin{array}{c}\text { SI for both of the two crops } \\
\text { (i.e. } 100 \% \text { SI) }\end{array}$ & $\begin{array}{c}\text { SI for both of the two crops } \\
\text { (i.e. } 100 \% \text { SI) }\end{array}$ \\
\hline
\end{tabular}

\subsection{Response of soil C to SI under different textured soils}

Compared with coarse-textured soils, it is widely regarded that fine-textured soils contain more soil C (Li et al. 1994; Franzluebbers et al. 1996; Wang et al. 2008), because fine-textured soils are favourable to $\mathrm{C}$ protection, and reduce in $\mathrm{C}$ decomposition rates (Sukkariyah et al. 2007). In practice, a strong interaction between tillage management and soil texture has been observed. Previous studies reported reduced tillage resulted in greater soil organic $\mathrm{C}$ accumulation than PT treatment in fine-textured soils, whereas in coarse-textured soils, tillage practices had no affect on soil C content (Needelman et al. 1999; Chivenge et al. 2007; Melero et al. 2009). These findings combined with the C-saturated model (Six et al. 2002) are a viable explanation for our results regarding tillage effects on different textured soils. Additionally, our results showed that irrespective of soil texture, soil C progressively increased with increasing SI amounts. This finding was inconsistent with Chivenge et al. (2007), who reported straw management was of substantial importance to increase soil $\mathrm{C}$ in coarse-textured but not fine-textured soils, which might reflect lower overall levels of soil C in Chinese croplands.

\subsection{Estimates of soil C sequestration under SI in China}

Based on the Second Soil Survey and China Landcover 2010 database, we estimated total surface soil organic C in cropland soils was $4.05 \mathrm{Pg} \mathrm{C}$. SI could sequester $405 \mathrm{Tg} \mathrm{C}$ during the first 5 years, with an average of $81 \mathrm{Tg} \mathrm{C}$ year $^{-1}$ according to our current data. Over a longer period (20 years), soil $\mathrm{C}$ sequestration could potentially reach $688 \mathrm{Tg} \mathrm{C}$, with an average of

Table 4 Estimates of potential carbon sequestration by SI

\begin{tabular}{|c|c|c|c|c|}
\hline Region & Scenarios & $\begin{array}{l}\mathrm{C} \text { sequestration } \\
\text { rate }\left(\mathrm{Tg} \mathrm{C} \text { year }^{-1}\right)\end{array}$ & $\begin{array}{l}\text { Potential of } \mathrm{C} \\
\text { seqestration }(\mathrm{Tg} \mathrm{C})\end{array}$ & Source \\
\hline Global & $100 \% \mathrm{SI}$ & 200 & & Lal 1997 \\
\hline USA & $50 \% \mathrm{SI}$ & $11.2-22.4$ & & Follett 2001 \\
\hline EU15 & $100 \% \mathrm{SI}$ & 14.02 & 1400 & Smith et al. 1997 \\
\hline \multirow[t]{2}{*}{ Europe } & $2 \mathrm{t} \mathrm{ha}^{-1}$ year $^{-1}$ & 1.09 & & Smith et al. 2000 \\
\hline & $10 \mathrm{t} \mathrm{ha}^{-1}$ year $^{-1}$ & 6.49 & & \\
\hline Australia & SI over 25 years & & $31 \%$ & Luo et al. 2010 \\
\hline \multirow[t]{7}{*}{ China } & $100 \% \mathrm{SI}$ & $36.8-52.1$ & & Sun et al. 2010 \\
\hline & $50 \% \mathrm{SI}$ & 23.2 & 231.8 & Yan et al. 2007 \\
\hline & $100 \% \mathrm{SI}$ & 57.1 & 1146.2 & \\
\hline & $30 \% \mathrm{SI}$ & 9.76 & & Lu et al. 2009 \\
\hline & $100 \% \mathrm{SI}$ & 34.4 & & \\
\hline & Scenario I & 48.2 & 531 & In this study \\
\hline & Scenario II & 56.2 & 618 & \\
\hline
\end{tabular}


34.4 Tg C year ${ }^{-1}$. Chinese croplands are catalogued into single and double crops. The northeast and northwest regions harvest a single annual crop, while the northern and southern regions produce double annual crops (Table 2). In practice, due to labour costs and energy-consumption for SI practices, a number of regions implement single-crop SI (Zhang et al. 2007), particularly in the north and south (i.e. the double-crop regions). We propose the following two Scenarios: in Scenario I, if single-crop SI was implemented in croplands across all of China's agricultural regions (Table 3), the potential soil C sequestration could reach $531 \mathrm{Tg} \mathrm{C}$, with an average $48.2 \mathrm{Tg} \mathrm{C}$ year $^{-1}$; in Scenario II, full utilisation of single- and double-crop straw (Table 3) could further enhance the potential soil $\mathrm{C}$ sequestration to $618 \mathrm{Tg} \mathrm{C}$, with an average $56.2 \mathrm{Tg} \mathrm{C}$ year $^{-1}$. The soil $\mathrm{C}$ sequestration amounts in Scenarios I and II could respectively account for $2.43 \%$ and $2.83 \%$ of the C emissions from fuel use in China in 2010 (2.18 Pg C, IEA 2011). Soil C sequestration following adoption of SI in our results was slightly higher than in other reports from China (Table 4), because straw inputs were underestimated in previous reports (Yan et al. 2007; $\mathrm{Lu}$ et al. 2009; Sun et al. 2010). Overall, soil C sequestration rates in China were higher than in Europe and the United States (Table 4), which might be attributable to the relatively larger initial soil organic C content in the other countries ( $\mathrm{Li}$ et al. 2003).

\section{Conclusions}

The results of our meta-analysis demonstrated that straw incorporation (SI) has considerable potential to sequester surface soil $\mathrm{C}$ in Chinese croplands, and SI effects on soil C storage are highly dependent on the type and amount of straw, tillage treatment, cropping system, experimental region, and duration of SI. The application of larger chopped straw amounts over a longer duration was more favourable to soil $\mathrm{C}$ sequestration. Furthermore, soils with serious $\mathrm{C}$ loss, such as soils in the northwest and northeast regions, and soils experiencing tillage treatments and upland cropping, exhibited increased potential to sequester soil $\mathrm{C}$ following SI implementation. Following data analysis, we estimated during the first 5 years, SI could sequester $81 \mathrm{Tg} \mathrm{C}$ year $^{-1}$, and approximately $34.4 \mathrm{Tg} \mathrm{C}$ year $^{-1}$ in the long term. If singleand double-crop straw were fully utilised, then soil $\mathrm{C}$ sequestration potential could reach a respective 48.2 and $56.2 \mathrm{Tg} \mathrm{C}$ year $^{-1}$, equivalent to 2.43 and $2.83 \%$ of the $\mathrm{C}$ emissions from fuel combustion in China in 2010.

China is currently experiencing notable societal and economic transitions, and agriculture is sharing in the rapid changes occurring in the country. The popularisation of electric power, fossil fuel use in rural areas, and increased labour costs for collecting straw has limited or eliminated its use for fuel and forage. China has become the world's largest producer of $\mathrm{CO}_{2}$ emissions, and simultaneously subject to substantial soil C loss. As a single agricultural management which shows concurrently increase in both carbon storage and crop yield, returning crop straws to the soil may be a promising option for the enhancement of $\mathrm{C}$ sequestration in cropland.

Acknowledgments We are grateful to the authors of the papers included in this study, including Deshui Tan, Jing Yang, Huaping Duan, Guanghua Wang and Huiping Qu etc. for providing the data for our study. We also acknowledge Yafei Yuan for constructive comments and suggestions on this paper. This work was supported by the National Natural Science Foundation of China (Grant No. 71003092), the 'Strategic Priority Research Program-Climate Change: Carbon Budget and Relevant Issues' of the Chinese Academy of Sciences (Grant No. XDA05050602 and XDA05060102), and the Ministry of Science and Technology of the People's Republic of China (Grant No. 2010CB833504-03 


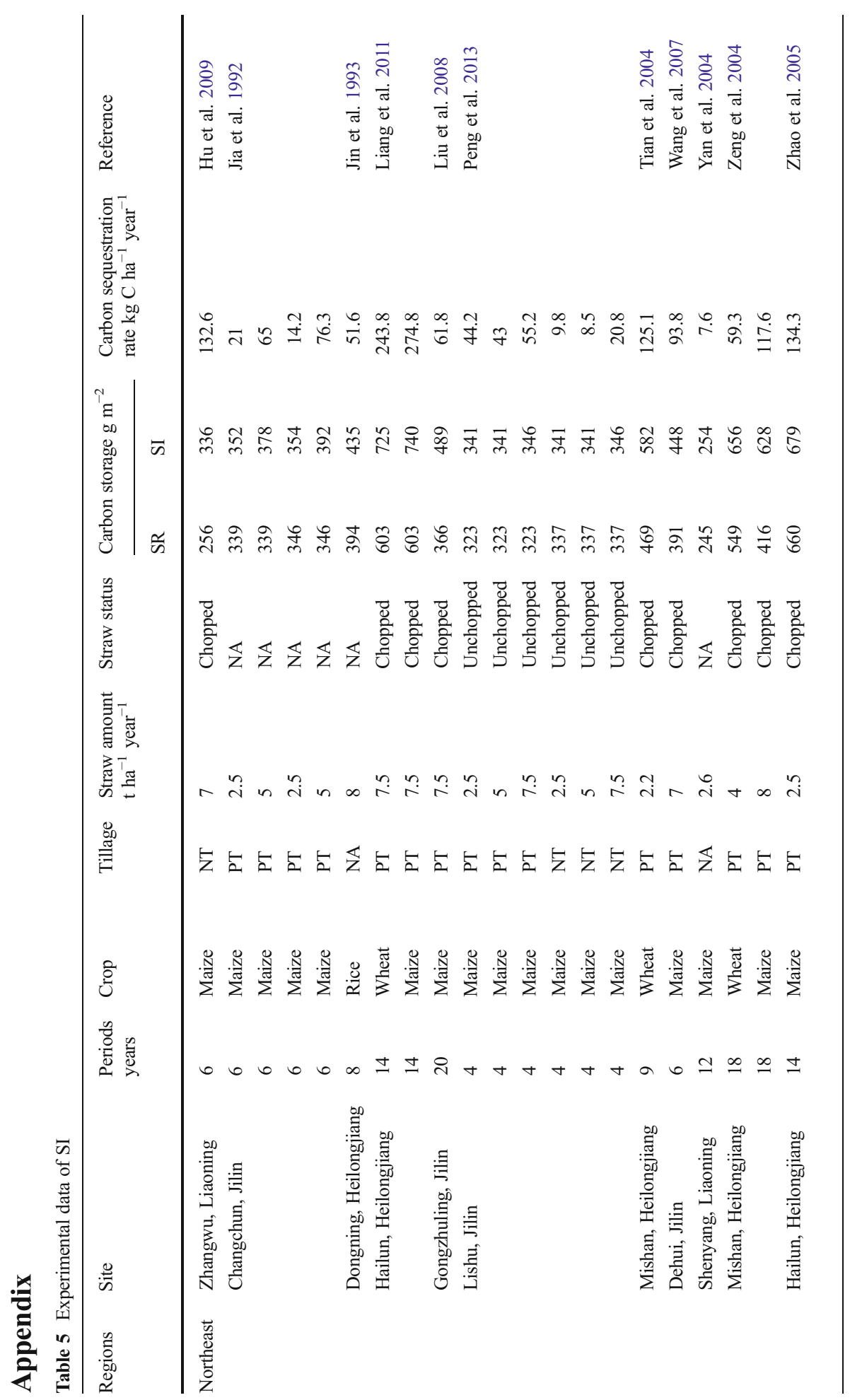




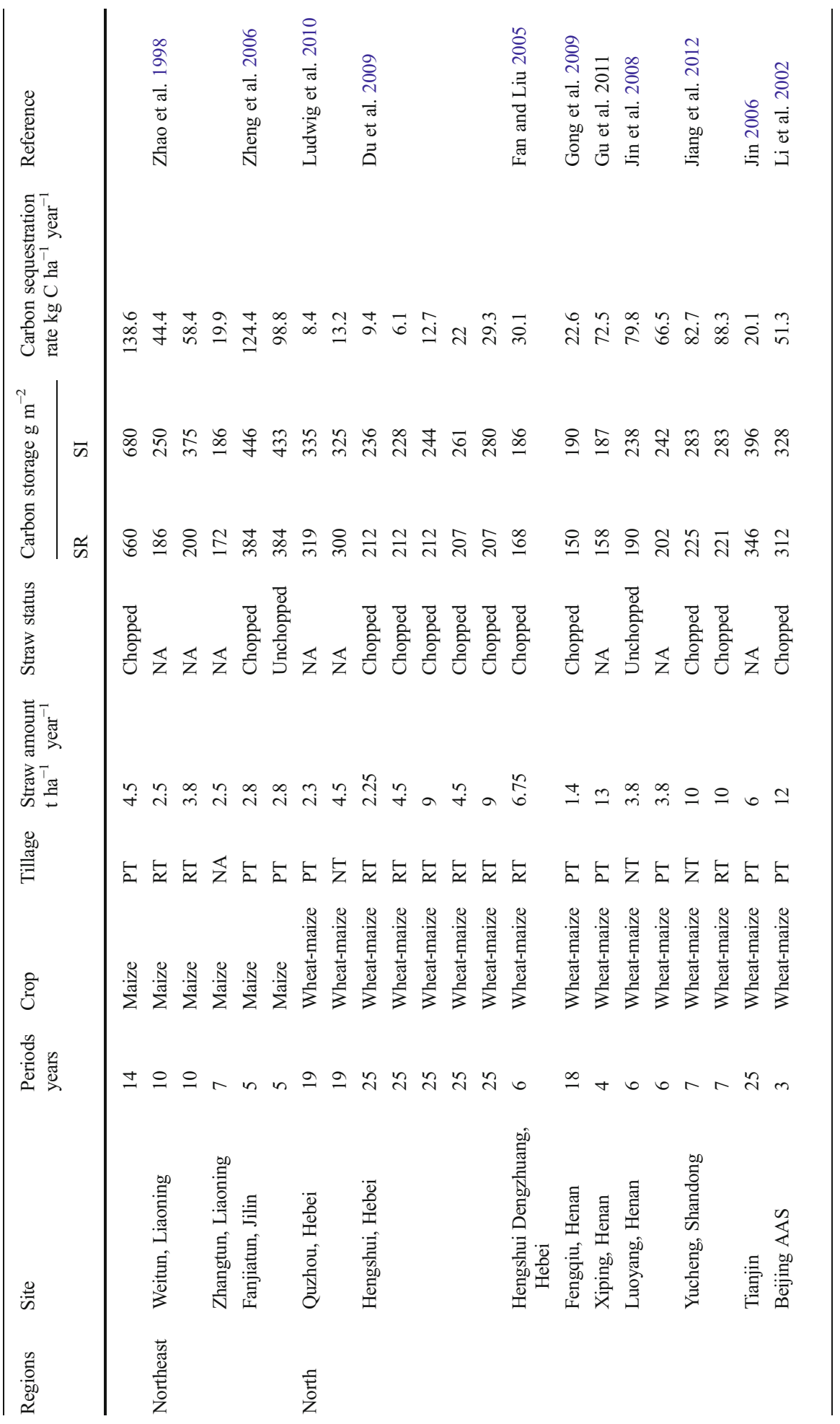




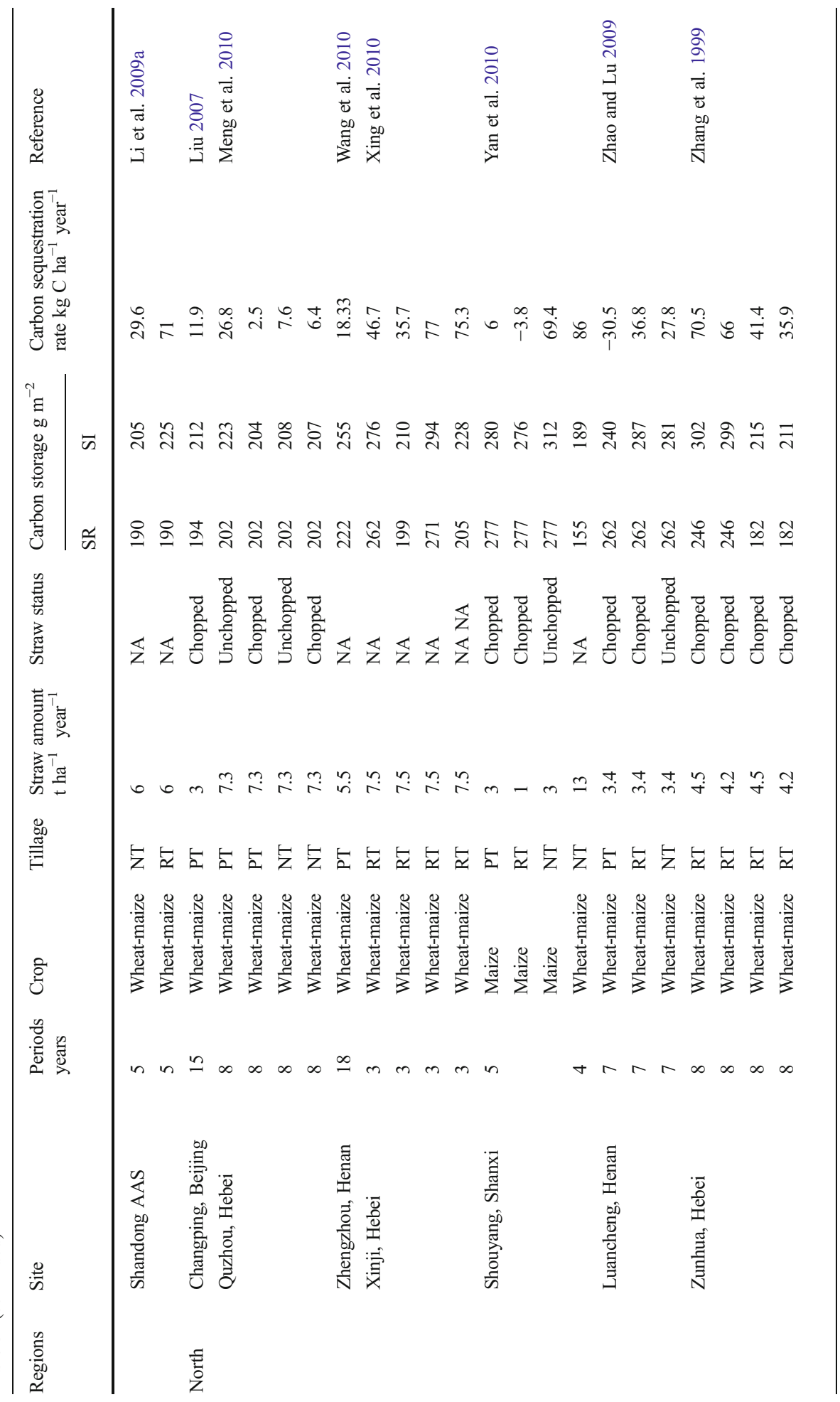




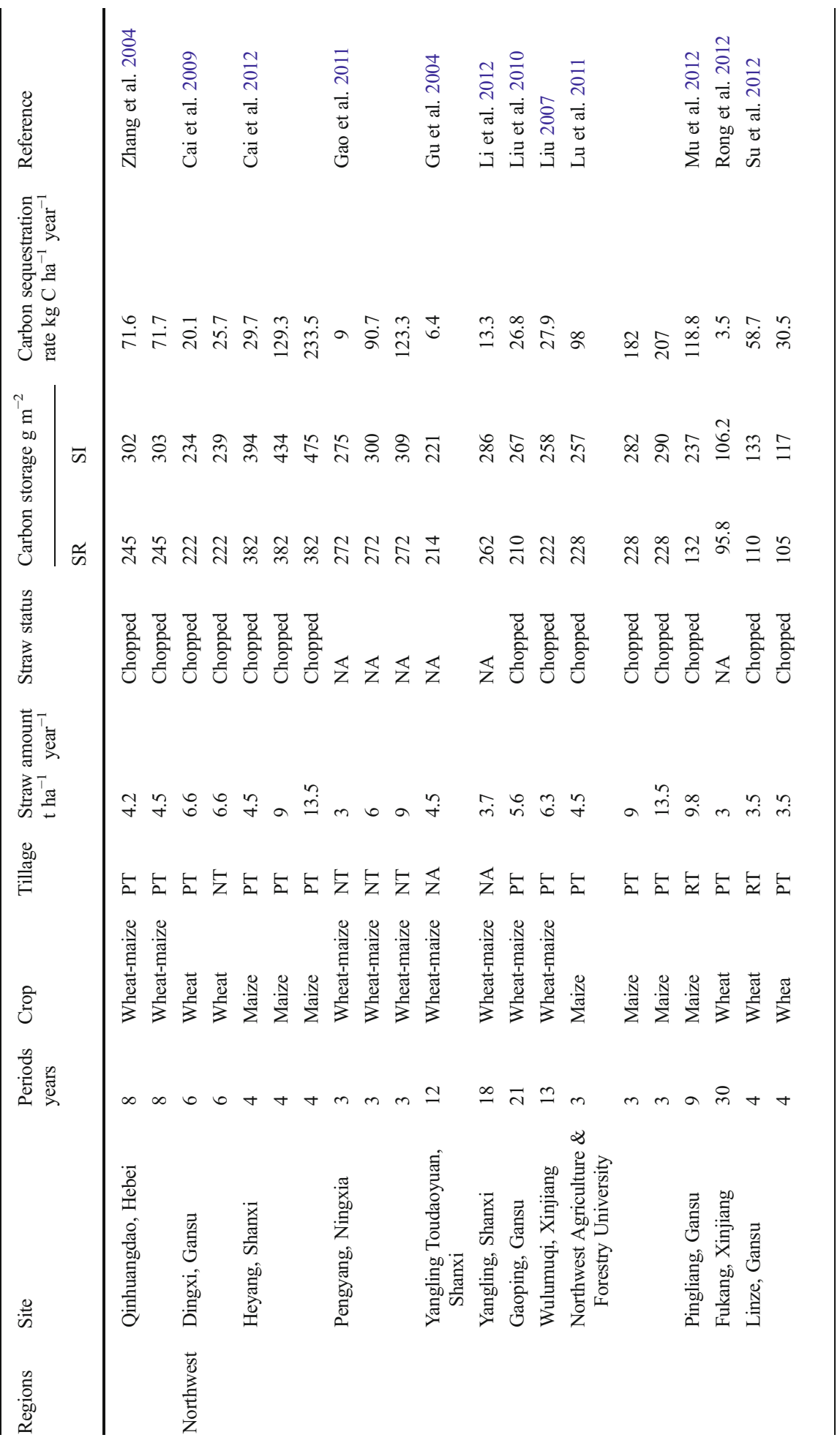




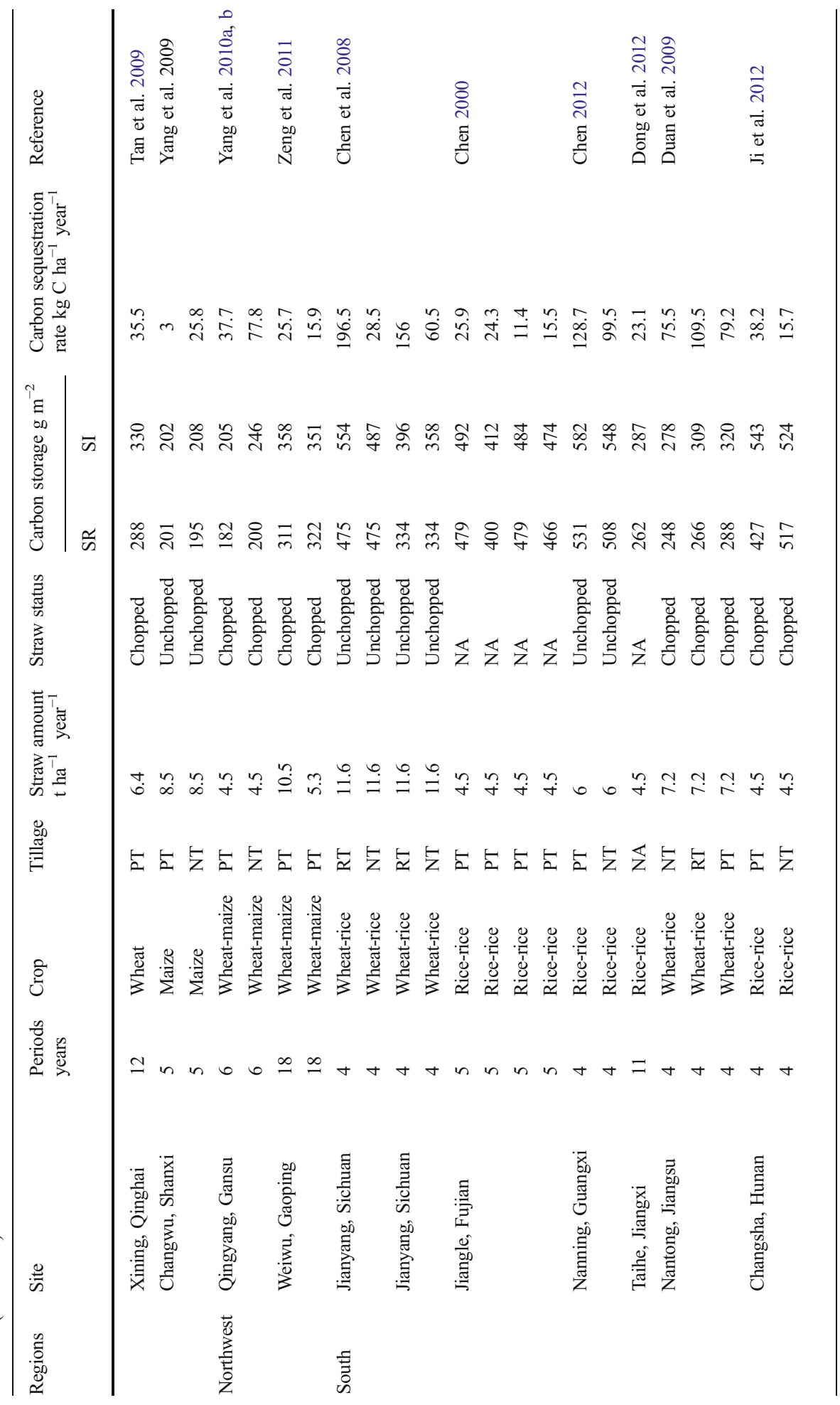




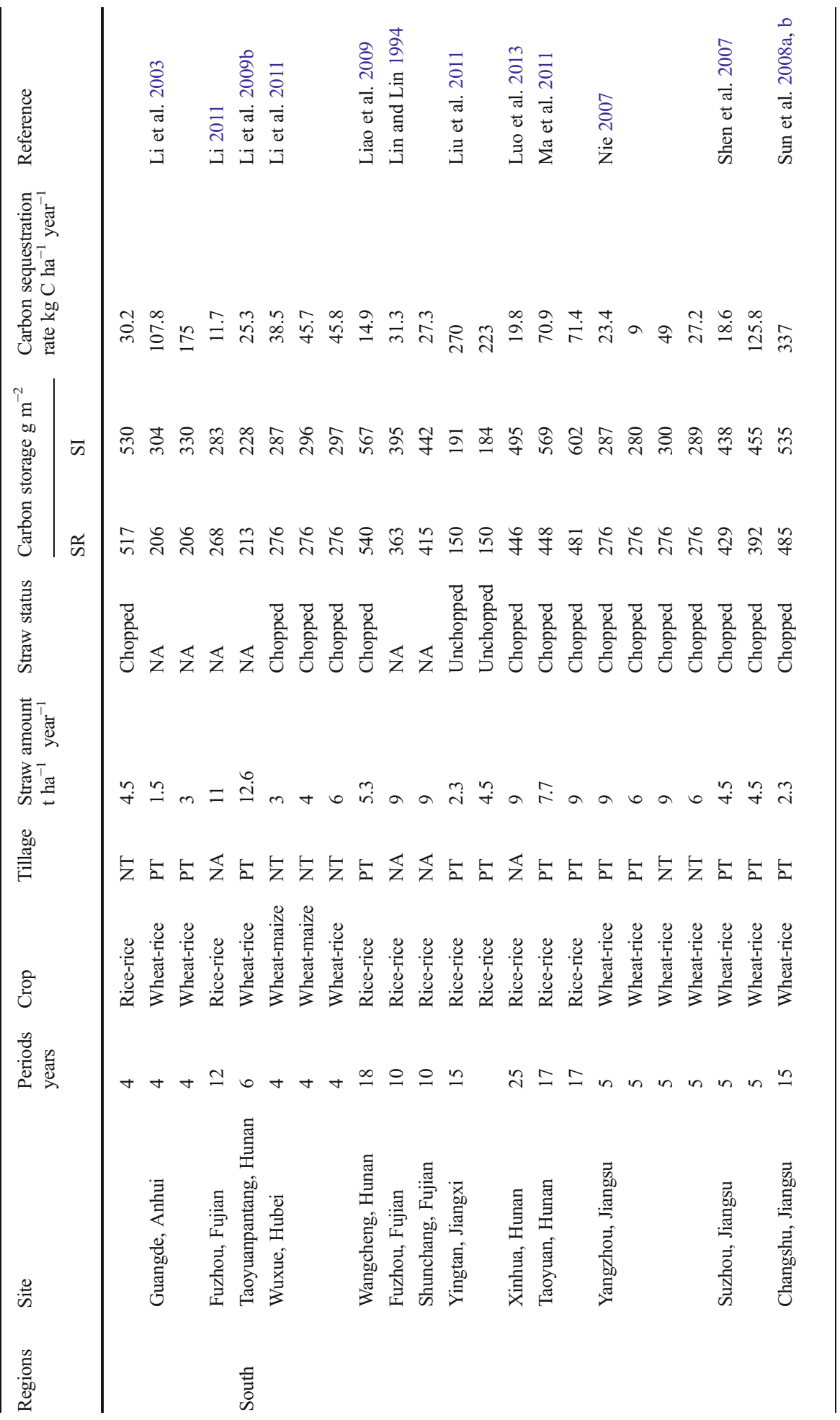









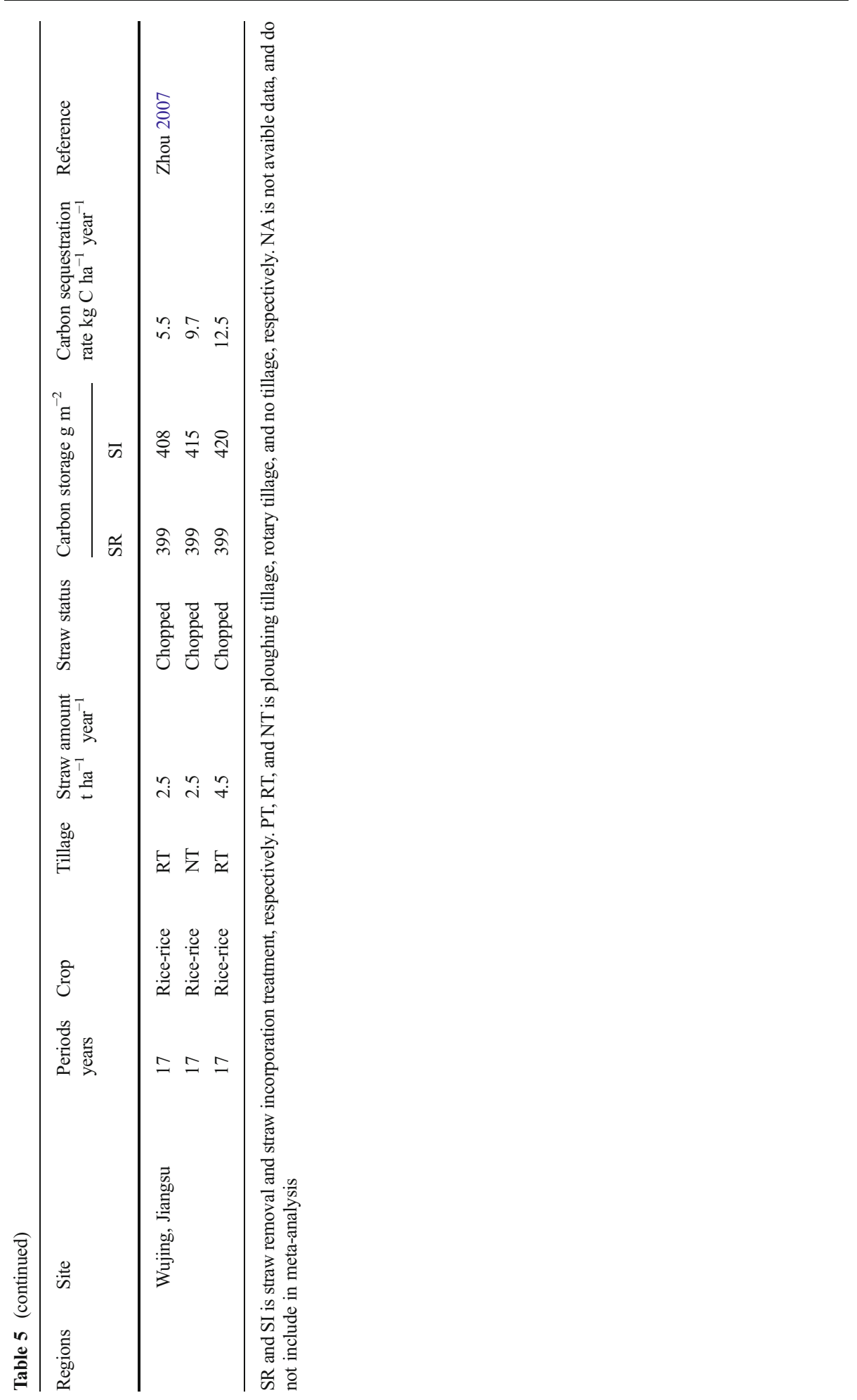




\section{References}

Allmaras RR, Copeland SM, Copeland PJ et al (1996) Spatial relations between oat residue and ceramic spheres when incorporated sequentially by tillage. Soil Sci Soc Am J 60:1209-1216

Álvaro-Fuentes J, López MV, Arrúe JL et al (2009) Tillage and cropping effects on soil organic carbon in Mediterranean semiarid agroecosystems: testing the century model. Agric Ecosyst Environ 134:211-217

Bi Y, Kou J, Wang D (2008) Comprehensive utilization technology of straw resources in China. Chinese Agricultural Science and Technology Publishing House, Beijing (in Chinese)

Bossuyt H, Six J, Hendrix PF (2002) Aggregate-protected carbon in no-tillage and conventional tillage agroecosystems using carbon-14 labeled plant residue. Soil Sci Soc Am J 66:1965-1973

Chivenge PP, Murwira HK, Giller KE et al (2007) Long-term impact of reduced tillage and residue management on soil carbon stabilization: implications for conservation agriculture on contrasting soils. Soil Tillage Res 94:328-337

Curtis PS, Wang X (1998) A meta-analysis of elevated $\mathrm{CO}_{2}$ effects on woody plant mass, form, and physiology. Oecologia 113:299-313

Department of Science and Technology and Education, Ministry of Agriculture of the Peple's Republic of China, STEMOA (2010) Survey and access report of national crop straw source http://d.wanfangdata.com.cn/ Periodical_nygcjs201102002.aspx

Devêvre OC, Horwáth WR (2000) Decomposition of rice straw and microbial carbon use efficiency under different soil temperatures and moistures. Soil Biol Biochem 32:1773-1785

Dick RP (1992) A review: long-term effects of agricultural systems on soils biochemical and microbial parameters. Agric Ecosyst Environ 40:25-36

Dobermann A, Fairhurst T (2000) Rice: nutrient disorders and nutrient management. International Rice Research Institute, the Philippines

Dolan MS, Clappa CE, Allmarasa RR et al (2006) Soil organic carbon and nitrogen in a Minnesota soil as related to tillage, residue and nitrogen management. Soil Tillage Res 89:221-231

Feng ZZ, Kobayashi K, Ainsworth EA (2008) Impact of elevated ozone concentration on growth, physiology, and yield of wheat (Triticum aestivum L.): a meta-analysis. Global Change Biol 14:2696-2708

Follett RF (2001) Soil mangement concepts and carbon sequestration cropland soils. Soil Tillage Res 61:77-92

Franzluebbers AJ, Haney RL, Hons FM et al (1996) Active fractions of organic matter in soils with different textures. Soil Biol Biochem 28:1367-1372

Gullett B, Touati A (2003) PCDD/F emissions from burning wheat and rice field residue. Atmos Environ 37: 4893-4899

Gurevitch J, Hedges LV (1999) Statistical issues in ecological meta-analyses. Ecology 80:1142-1149

Hermle S, Anken T, Leifeld J et al (2008) The effect of the tillage system on soil organic carbon content under moist, cold-temperate conditions. Soil Tillage Res 98:94-105

Huang S, Sun Y, Zhang W (2012) Changes in soil organic carbon stocks as affected by cropping systems and cropping duration in China's paddy fields: a meta-analysis. Clim Chang 112:847-858

Huggins DR, Allmaras RR, Clapp CE et al (2007) Corn-soybean sequence and tillage effects on soil carbon dynamics and storage. Soil Sci Soc Am J 71:145-154

IEA (2011) $\mathrm{CO}_{2}$ emissions from fueal combustion highlighys (2011 editions). http://www.iea.org/ $\mathrm{CO}_{2}$ highlights/ $\mathrm{CO}_{2}$ highlights.pdf

Kimetu JM, Lehmann J, Kinyangi JM et al (2009) Soil organic C stabilization and thresholds in C saturation. Soil Biol Biochem 41:2100-2104

Kwabiah AB, Palm CA, Stoskop NC et al (2003) Response of soil microbial biomass dynamics to quality of plant materials with emphasis on P availability. Soil Biol Biochem 35:207-216

Lal R (1997) Residue management, conservation tillage and soil restoration for mitigation greenhouse effect by $\mathrm{CO}_{2}$ enrichment. Soil Tillage Res 43:81-107

Lal R (2004) Soil C sequestration impacts on global climatic change and food security. Science 304:16231627

Lal R, Follett F, Stewart BA et al (2007) Soil carbon sequestration to mitigate climate change and advance food security. Soil Sci 172:943-956

Li C, Frolking S, Harriss R (1994) Modeling carbon biogeochemistry in agricultural soils. Glob Biogeochem Cycles 8:237-254

Li XJ, Zhang ZG, Li YX (2001) Effects of soil depth on decay speed of straw. Acta Pedol Sin 38:135-138 (in Chinese)

Li CS, Zhuang YH, Frolking S et al (2003a) Modeling soil organic carbon change in croplands of China. Ecol Appl 13:327-336

Liu X, Gao W, Zhu W (2001) Mechanism and techniques of straw returning. China Agriculture Press, Beijing (In Chinese) 
Lu F, Wang XK, Han B et al (2009) Soil carbon sequestrations by nitrogen fertilizer application, straw return and no-tillage in China's cropland. Glob Chang Biol 15:281-305

Lu F, Wang XK, Han B et al (2010a) Net mitigation potential of straw return to Chinese cropland: estimation with a full greenhouse gas budget model. Ecol Appl 20(3):634-647

Lu F, Wang XK, Han B et al (2010b) Modeling the greenhouse gas budget of straw returning in China. Ann N Y Acad Sci 1195:107-130

Luo ZK, Wang EL, Sun JX (2010) Soil carbon change and its responses to agricultural practices in Australian agro-ecosystems: a review and synthesis. Geoderma 155:211-223

Melero S, López-Garrido R, Madejón E et al (2009) Long-term effects of conservation tillage on organic fractions in two soils in southwest of Spain. Agric Ecosyst Environ 133:68-74

Ministry of Agriculture of the PRC (2011) National Modern Agriculture Development Plan 2011-2015. http:// english.agri.gov.cn/hottopics/five/

Morgan PB, Ainsworth EA, Long SP (2003) How does elevated ozone impact soybean? A meta-analysis of photosynthesis, growth and yield. Plant Cell Environ 26: 1317-1328

Needelman BA, Wander MM, Bollero GA et al (1999) Interaction of tillage and soil texture: biologically active soil organic matter in Illinois. Soil Sci Soc Am J 63:1326-1334

Pan G, Smith P, Pan W (2009) The role of soil organic matter in maintaining the productivity and yield stability of cereals in China. Agric Ecosyst Environ 129:344-348

Pan G, Xu XM, Smith P et al (2010) An increase in topsoil SOC stock of China's croplands between 1985 and 2006 revealed by soil monitoring. Agric Ecosyst Environ 136:133-138

Pan G, Crowley D, Lehmann J (2011) Burn to air or burial in soil: the fate of China's straw residues, IBI web post

Powlson DS, Glendining MJ, Coleman K et al (2011) Implications for soil properties of removing cereal straw: results from long-term studies. Agron J 103:279-287

Rosenberg MS, Adams DC, Gurevitch J (2000) Metawin: statistical software for meta-analysis, version 2.1. Sinauer Associates, Inc, Sunderland

Rui WY, Zhang WJ (2010) Effect size and duration of recommended management practices on carbon sequestration in paddy field in Yangtze Delta Plain of China: a meta-analysis. Agric Ecosyst Environ 135: 199-205

Saffih-Hdadia K, Mary B (2008) Modeling consequences of straw residue straws export on soil organic carbon. Soil Biol Biochem 40:594-607

Six J, Conant RT, Paul EA et al (2002) Stabilization mechanisms of soil organic matter: implications for Csaturation of soils. Plant Soil 241:155-176

Smith P (2004) Carbon sequestration in croplands: the potential in Europe and the global context. Eur J Agron 20:229-236

Smith P, Powlson DS, Glendining MJ et al (1997) Potential for carbon sequestration in European soils: preliminary estimates for five scenarios using results from long-term experiments. Glob Chang Biol 3:67-79

Smith P, Powlson DS, Glendining MJ et al (2000) Meeting Europe's climate change commitments: quantitative estimates of the potential for carbon mitigation by agriculture. Glob Chang Biol 6:525-539

Song GH, Li LQ, Pan GX et al (2005) Top soil organic carbon storage of China and its loss by cultivation. Biogeochemistry 74:47-62

Stemmer M, von Lützow M, Kandeler E et al (1999) The effect of maize straw placement on mineralization of C and $\mathrm{N}$ in soil particle size fractions. Eur J Soil Sci 50:73-86

Sukkariyah B, Evanylo G, Zelazny L et al (2007) Distribution of copper, zinc, and phosphorus in Coastal Plain soils receiving repeated liquid biosolids applications. J Environ Qual 36:1618-1626

Sun W, Huang Y, Zhang W et al (2010) Carbon sequestration and its potential in agricultural soils of China. Glob Biogeochem Cycles. doi:10.1029/2009GB003484

Wang L, Qiu J, Tang H et al (2008) Modelling soil organic carbon dynamics in the major agricultural regions of China. Geoderma 147:47-55

Wang GC, Luo ZK, Wang EL et al (2013) Contrasting effects of agricultural management on soil organic carbon balance in different agricultural regions of China. Pedosphere 23(6):717-728

West TO, Post WM (2002) Soil organic carbon sequestration rates by tillage and crop rotation: a global data analysis. Soil Sci Soc Am J 66:1930-1946

Wingeyer AB, Walters DT, Drijber RA et al (2012) Fall conservation deep tillage stabilizes maize residues into soil organic matter. Soil Sci Soc Am J 76:2154-2163

Witt C, Cassman KG, Olk DC et al (2000) Crop rotation and residue management effects on carbon sequestration, nitrogen cycling and productivity of irrigated rice systems. Plant Soil 225:263-278

Wittig VE, Ainsworth EA, Long SP (2007) To what extent do current and projected increases in surface ozone affect photosynthesis and stomatal conductance of trees? A meta-analytic review of the last 3 decades of experiments. Plant Cell Environ 30:1150-1162 
Wu T, Schoenau JJ, Li F et al (2004) Influence of cultivation and fertilization on total organic carbon and carbon fractions in soils from the Loess Plateau of China. Soil Tillage Res 77:59-68

Wu J, Huang M, Xiao HA et al (2007) Dynamics in microbial immobilization and transformations of phosphorus in highly weathered subtropical soil following organic amendments. Plant Soil 290:333-342

Xie Z, Zhu J, Liu G et al (2007) Soil organic carbon stocks in China and changes from 1980s to 2000s. Glob Chang Biol 13:1989-2007

Xu MG, Lou YL, Sun XL et al (2011a) Soil organic carbon active fractions as early indicatorsfor total carbon change under straw incorporation. Biol Fertil Soils 47:745-752

Yan H, Cao M, Liu J et al (2007) Potential and sustainability for carbon sequestration with improved soil management in agricultural soils of China. Agric Ecosyst Environ 121:325-335

Ye LL, Wang CH, Peng XH et al (2010) Effect of sling on soil quality. Hunan Agric Sci 19:52-55 (in Chinese with English abstract)

Yu Y, Guo Z, Wu H et al (2009) Spatial changes in soil organic carbon density and storage of cultivated soils in China from 1980 to 2000. Glob Biogeochem Cycles 23, GB2021. doi:10.1029/2008GB003428

Yu Y, Huang Y, Zhang W (2012) Modeling soil organic carbon change in croplands of China, 1980-2009. Glob Planet Chang 82-83:115-128

Zhang B (2000) Severe status of agricultural eco-environment in China. China News, National edition, 6 June 2000: Domestic News

Zhang JX, Wang XN, Chen F et al (2007) Study on working parameters of knife roller of field straw chopper for mulching or reclaiming. Trans Chin Soc Agric Mach 38:82-85 (in Chinese with English abstract)

\section{Renference in Appendix}

Cai L, Qi P, Zhang R et al (2009) Effects of different conservation tillage measures on soil organic carbon pool in two sequence rotation systems of spring wheat and pease. Chin J Eco-Agric 17:16 (in Chinese with English abstract)

Cai T, Huang H, Huang Y et al (2012) Effects of different rates of straw mulching and returning to field on soil labile organic carbon and carbon pool management index. J Nat Res 27:964-974 (in Chinese with English abstract)

Chen (2012) The Effect of conservation tillage on changes of soil organic carbon and the function mechanism. Guangxi University (in Chinese with English abstract)

Chen D (2000) Effects of rice straw return on soil physical and chemical properties and yield. Soil Fertil 5:24-27 (in Chinese with English abstract)

Chen S, Liu D, Zhu Z et al (2008) Effects of straw-mulching and no-tillage on soil nutrients and carbon pool in Sichuan Basin. Sci Soil Water Conserv 6:54-56 (in Chinese with English abstract)

Dong W, Zhang X, Wang H et al (2012) Effect of different fertilizer application on the soil fertility of paddy soils in red soil region of southern China. PLoS ONE 7(9):e44504. doi:10.1371/journal. pone.0044504

Du Z, Liu S, Li K et al (2009) Soil organic carbon and physical quality as influenced by long-term application of residue and mineral fertiliser in the North China Plain. Soil Res 47:585-591

Duan H, Niu Y, Li F et al (2009) Effects of tillage styles and straw return on soil carbon sequestration and crop yields of direct seeding rice. Jiangsu J Agric Sci 25:706-708 (in Chinese with English abstract)

Fan B, Liu Q (2005) Effect of conservation tillage and straw application on the soil microorganism and Pdissolving characteristics. Chin J Eco-Agric 13:130-132 (in Chinese with English abstract)

Gao FM, Jia Z, Zhang P et al (2011) Effect of straw mulching on soil active organic carbon and soil C pool management index in the arid areas of Southern Ningxia. Agric Res Arid Areas 29:107-111 (in Chinese with English abstract)

Gong W, Yan X, Wang J et al (2009) Long-term manuring and fertilization effects on soil organic carbon pools under a wheat-maize cropping system in North China Plain. Plant Soil 314:67-76

Gu Q, Yang X, Sun B et al (2004) Effects of long-term fertilization and irrigation on soil nutrient distribution in profiles of Loess soil. Soil Fertil Sci 20:139-147 (in Chinese with English abstract)

$\mathrm{Hu}$ N, Lou H, Liang L et al (2009) Soil organic C and N stocks as affected by the conservation tillage. Ecol Environ Sci 18:223-226, in Chinese with English abstract

Ji X, Wu J, Peng H et al (2012) The effect of rice straw incorporation into paddy soil on carbon sequestration and emissions in the double cropping rice system. J Sci Food Agric 92:1038-1045

Jia S, Wang S, Jiang Y et al (1992) Effect of fertilization on soil fertility and maize yield and quality. J Jilin Agric Univ 14:58-62 (in Chinese)

Jiang X, Li Y, Ouyang Z et al (2012) Effect of no-tillage on soil aggregate and organic carbon storage. Chin J Eco-Agric 20:270-278 (in Chinese with English abstract) 
Jin C, Quan J, Ma Y et al (1993) Report of field rice straw return. Heilongjiang Agric Sci 1:21-23 (in Chinese with English abstract)

Jin H (2006) Carbon sequestration characteristics in soil under different soil management practices. China Agricultural University

Jin K, DeNeve S, Bram M et al (2008) Effects of different soil management practices on winter wheat yield and $\mathrm{N}$ losses on a dryland loess soil in China. Aust J Soil Res 46:455-463

Li C, Kou Z, Zhang Z et al (2011) Effects of rape residue mulch on greenhouse gas emissions and carbon sequestration from no-tillage rice fields. J Agro-Environ Sci 30:2362-2367 (in Chinese with English abstract)

Li H, Zhou L, Zhang Y et al (2002) Influence of straw returning to farmlands upon soil moisture and fertilizer preservationm and crop yield. China Rural Water Hydropower 1:36-38 (in Chinese with English abstract)

Li J, Li Q, Li P et al (2012) Effects of long-term organic inputs on distribution of aggregate size and its organic carbon content on lou soil. Chin J Soil Sci 43:1456-1460 (in Chinese with English abstract)

Li L, Wang Z, Wang X et al (2009a) Effects of soil surface mulching on organic carbon, inorganic carbon and light fraction organic carbon in dryland soil. Plant Nutr Fertil Sci 15:479-483 (in Chinese with English abstract)

Li L, Zhu H, Su Y et al (2009b) Effects of rice straw incorporation in situ and ex situ on soil organic C and active organic C in agricultural soils in red soil hilly region. Sci Agric Sin 42:926-933 (in Chinese with English abstract)

Li Q (2011) Effects of long-term fertilization on carbon nitrogen fractions and microbial diversity in red paddy soil. Fujian Agriculture and Forestry University (in Chinese with English abstract)

Li X, Wu J, Zhu H et al (2003) Effect of straw return on crop yield and soil nutient. J Anhui Agric Sci 31:870871 (in Chinese with English abstract)

Liang Y, Han X, Song C et al (2011) Impacts of returning organic materials on soil labile organic carbon fractions redistribution of Mollisol in Northeast China. Sci Agric Sin 44:3565-3574 (in Chinese with English abstract)

Liao Y, Zheng S, Nie J et al (2009) Effects of long-term application of fertilizer and rice straw on soil fertility and sustainability of a reddish paddy soil productivity. Sci Agric Sin 42:3541-3550 (in Chinese with English abstract)

Lin Y, Lin Z (1994) Effects of rice return on soil fertility and crop yield. Fujian Agric Sci Technol 3:8-10 (in Chinese with English abstract)

Liu E (2007) Microbiological features of soils under different fertilization systems and their related soil fertility. Chinese Academy of Agricultural Sciences Ph.D Dissertation (in Chinese with English abstract)

Liu E, Yan C, Mei X et al (2010) Long-term effect of chemical fertilizer, straw, and manure on soil chemical and biological properties in northwest China. Geoderma 158:173-180

Liu H, Lin Y, Wang X, Tan X et al (2007) Effect of long-term application of straw on grey desert soil quality. Ecol Environ 16:1492-1497 (in Chinese with English abstract)

Liu M, Li Z, Zhang T et al (2011) Discrepancy in response of rice yield and soil fertility to long-term chemical fertilization and organic amendments in paddy soils cultivated from infertile upland in subtropical China. Agric Sci China 10:259-266

Liu S, Wang Y, Zhou P et al (2008) Effect of various fertilization on the oprgano-mineral complexation and the combined forms of humus of phaeozem. J Nanjing Agric Univ 31:76-80 (in Chinese with English abstract)

Lu W, Jia Z, Zhang P et al (2011) Effects of straw returning on soil labile organic carbon and enzyme activity in semi-arid areas of Southern Ningxia, China. J Agro-Environ Sci 30:522-528 (in Chinese with English abstract)

Ludwig B, Hu K, Niu L et al (2010) Modelling the dynamics of organic carbon in fertilization and tillage experiments in the North China Plain using the Rothamsted Carbon Model-initialization and calculation of C inputs. Plant Soil 332:193-206

Luo L, Zhou P, Tong C et al (2013) Study on mechanism of SOM stabilization of paddy soils under long-term fertilization. Environ Sci 34:692-697 (in Chinese with English abstract)

Ma L, Yang L, Xiao H et al (2011) Effects of fertilization and straw returning on distribution and mineralization of organic carbon in paddy soils in subtropical China. Soils 43:883-890 (in Chinese with English abstract)

Meng F, Kuang X, Du Z et al (2010) Impact of land use change and cultivation measures on soil organic carbon (SOC) and its ${ }^{13} \mathrm{C}$ values. Environ Sci 1733-1739 (in Chinese with English abstract)

Mu P, Zhang E, Wang H et al (2012) Effects of continuous straw return to soil on maize growth and soil chemical and physical characteristics. Chin J Eco-Agric 20:291-296 (in Chinese with English abstract)

Nie X (2007) Effects of no-tillage plus straw returning on cropland eco-enviroment and wheat-rice productivity. Yangzhou University (in Chinese with English abstract)

Peng Y, Xie H, Li J et al (2013) Effect of no-tillage with different stalk mulching on soil organic carbon and midinfrared spectral characteristics. Sci Agric Sin 46:2257-2264 (in Chinese with English abstract) 
Rong J, Li C, Wang Y et al (2012) Effect of long-term fertilization on soil organic carbon and soil inorganic carbon in oasis cropland. Arid Zone Res 29:592-597 (in Chinese with English abstract)

Shen MX, Yang L, Ming Y et al (2007) Long-term effects of fertilizer managements on crop yields and organic carbon storage of a typical rice-wheat agroecosystem of China. Biol Fertil Soils 44:187-200

Su Y, Yang R, Yang X et al (2012) Effects of agricultural management practices on soil organic carbon and its fractions in newly cultivated sandy soil in Northwest China. Sci Agric Sin 45:2867-2876 (in Chinese with English abstract)

Sun W, Wang L, Jin J et al (1994) Effect of straw return on humus composition in rice soil in Suzhou region. Chin J Soil Sci 25:172-174 (in Chinese)

Sun X, Liu Q, Wang D et al (2008a) Effect of long-term application of straw on soil fertility. Chin J Eco-Agric 16:587-592 (in Chinese with English abstract)

Sun X, Liu Q, Wang D et al (2008b) Effect of long-term applicatioon of straw on soil fertility. Chin J Appl Ecol 16:587-592 (in Chinese with English abstract)

Tan D, Jin J, Huang S et al (2009) Study on effect of long-term application of K fertilizer and returning straw to soil on soil nutrient and wheat yield in the regions of castanozem. Agric Res Arid Areas 27:194-198 (in Chinese with English abstract)

Tian X, Ji J, Han X et al (2004) Effectsof long-term application of fertilizers on the contents and oxidable stability of organic matter in Albic soil. J Heilongjiang August First Land Reclam Univ 16:12-14 (in Chinese with English abstract)

Wang D, Li H, Hu F (2011) Effects of mulching and tillage on soil fertility of upland rice field. Acta Pedol Sin 48:1203-1209 (in Chinese with English abstract)

Wang G, Qi X, Jin J et al (2007) Effect of fertilization on total soil C, microbial biomass C and soil enzyme activities in farmland black soil. Chin J Soil Sci 38:661-666 (in Chinese with English abstract)

Wang J, Lu C, Zhang J et al (2010) Roth C model simulation of soil organic carbon dynamics of fluvo-aquic soil in Northern China. Chin Soil Fertil 6:15-21 (in Chinese with English abstract)

Wang X, Shi X, Song G (2005) Effects of long-term rice straw returning on the fertility and productivity of purplish paddy soil. Plant Nutr Fertil Sci 11:302-307

Wu J (2012) Effects of straw return on soil fertility and crop yields paddy-upland rotation system. Huazhong Agricultural University (in Chinese with English abstract)

Xie L (2011) Distribution characteristics of soil organic carbon and total nitrogen under long-term fertilization in typical arable land soil of China. Chinese Academy of Agricultural Sciences Dissertation (in Chinese with English abstract)

Xing S, Han B, Liu M et al (2010) The effect of NPK fertilizer combined with soil organic manure on soil nutrition and wheat yield increasing. J Agro-Environ Sci 29:135-140 (in Chinese with English abstract)

$\mathrm{Xu} \mathrm{S}$, Cui S, Chen F et al (2011) Effect of tillage on content of density fractions of paddy soil organic carbon and its spatial distribution. J Agro-Environ Sci 30:127-132 (in Chinese with English abstract)

$\mathrm{Xu} \mathrm{Y,} \mathrm{Chen} \mathrm{W,} \mathrm{Shen} \mathrm{Q} \mathrm{(2007)} \mathrm{Soil} \mathrm{organic} \mathrm{carbon} \mathrm{and} \mathrm{nitrogen} \mathrm{pools} \mathrm{impacted} \mathrm{by} \mathrm{long-term} \mathrm{tillage} \mathrm{and}$ fertilization practices. Commun Soil Sci Plant Anal 38:347-357 (in Chinese with English abstract)

$\mathrm{Xu} Z$ (2009) Effect of long-term located fertlization on the yields of rice and wheat and soil nutrient. Acta Agric Zhejiangensis 21:485-489 (in Chinese with English abstract)

Yan C, Liu E, He W et al (2010) Effect of different tillage on soil oragnic carbon and its fractions in the loess plateau of China. Chin Soil Fertil 6:58-63 (in Chinese with English abstract)

Yan L, Song Y, He J et al (2004) Effects of maize stems returning black to the field on the yield of plants and soil fertility. Chin J Soil Sci 35:143-148 (in Chinese with English abstract)

Yang J, Shen Y, Nan Z et al (2010a) Effects of conservation tillage on crop yield and carbon pool management index on top soil with in a maize wheat-soy rotation system in the Loess Plateau. Acta Pratacu Lturae Sin 19: 75-82 (in Chinese with English abstract)

Yang X, Hao M, Li F (2010b) Effect of long-term fertilization on wheat yield and nutrients absorption in Loess Plateau. Chin J Soil Sci 41:164-169 (in Chinese with English abstract)

Yu J, Li H, Chen X et al (2007) Effects of straw application and earthworm inoculation on soil labile organic carbon. Chin J Appl Ecol 18:818-824 (in Chinese with English abstract)

Zeng J, Guo T, Yu X et al (2011) Effect of fertilization on soil active C and C pool mangement index. Chin J Soil Sci 42:812-815 (in Chinese with English abstract)

Zeng L, Liu D, Hong Y et al (2004) Effects of long-term fertilization on soil nutrition and crop yield. J Heilongjiang August First Land Reclam Univ 19:22-26 (in Chinese with English abstract)

Zhang D, Han Z, Liu W et al (2004) Effect of application of maize straw with transformation promoter. J Hebei Vocat-tech Teach Coll 18:1-5 (in Chinese)

Zhang D, Han Z, Wang J et al (1999) Study on the technical regulation of straw directly returning to field in cinnamen soil in eastern areas of Hebei province. J Hebei Vocat-tech Teach Coll 13:1-6 (in Chinese) 
Zhang L, Xiao J, Xie D et al (2002) Study on microbial characteristics in paddy soil under long-term no-tillage and ridge culture. J Soil Water Conserv 16:111-114 (in Chinese with English abstract)

Zhang Y, Wang J, Nie G et al (2008) Effect of mechanized straw application on crop yield and soil labile carbon content. Jiangsu J Agric Sci 24:833-838 (in Chinese with English abstract)

Zhao H, Lu Y (2009) The effect of conservation tillage on the structural characteristics of Fluvo-aquic soil. Ecol Environ Sci 18:1956-1960 (in Chinese with English abstract)

Zhao L, Wang X, Wang S et al (2005) Changes of crop yield and soil fertility under long-term fertilization and nutrients-recycling and reutilization on a black soil. Chin J Appl Ecol 17:817-821 (in Chinese with English abstract)

Zhao X, Xu D, Gao Y (1998) Effect of maize straw return on soil fertility. Chin J Soil Sci 29:14-16 (in Chinese with English abstract)

Zheng L, Xie H, Zhang W et al (2006) Effects of different ways of returning straw to the soils on soluble organic carbon. Ecol Environ 15:80-83 (in Chinese with English abstract)

Zhou B (2007) Crop productivity and carbon sequestration effect of paddy field under different management in Southern Jiangsu: a case study of wujiang country. Nanjing Agricultural University (in Chinese with English abstract) 